\title{
Anxiety and depression in informal caregivers of dependent elderly people: an analytical study
}

\author{
Ansiedade e depressão em cuidadores informais de idosos dependentes: um estudo analítico \\ Ansiedad y depresión en cuidadores informales de ancianos dependientes: un estudio analítico
}

\section{Sarah Giulia Bandeira Felipe' ORCID: 0000-0001-5997-190X}

Camila Evangelista de Sousa Oliveira' ORCID: 0000-0002-1720-7011

Cynthia Roberta Dias Torres Silva' ORCID: 0000-0002-3331-2719

Polyana Norberta Mendes' ORCID: 0000-0002-2765-0236

Khelyane Mesquita de Carvalho' ORCID: 0000-0003-4270-3890

Fernando Lopes Silva-Júnior' ORCID: 0000-0002-0273-6738

Maria do Livramento Fortes Figueiredo' ORCID: 0000-0003-4938-2807

'Universidade Federal do Piauí. Teresina, Piauí, Brazil.

How to cite this article: Felipe SGB, Oliveira CES, Silva CRDT, Mendes PN, Carvalho KM, Silva-Júnio FL, et al. Anxiety and depression in informal caregivers of dependent elderly people: an analytical study.

Rev Bras Enferm. 2020;73(Suppl 1):e20190851. doi: http://dx.doi.org/10.1590/0034-7167-2019-0851

\section{Corresponding author:}

Cynthia Roberta Dias Torres Silva E-mail: cynthiarobertatorres@gmail.com

EDITOR IN CHIEF: Antonio José de Almeida Filho ASSOCIATE EDITOR: Ana Fátima Fernandes

\begin{abstract}
Objective: To analyze the symptoms of anxiety and depression in informal caregivers of dependent elderly at home. Methods: Analytical, cross-sectional study conducted in the city of Teresina (PI), with informal caregivers of dependent elderly people. Data collection took place from November 2017 to February 2018, using a characterization form for the dependent elderly and their caregiver, Beck's Anxiety Inventory (BAI) and Beck's Depression Inventory (BDI). The forward linear regression model was used to identify the predictive variables of anxiety and depression. Results: It was found that $18.4 \%$ of caregivers had symptoms of depression; and 14\%, moderate to severe anxiety. There was a correlation between anxiety and depression $(p=0.000)$. Conclusion: The findings of this study make it possible to assess anxiety and depression in caregivers of dependent elderly people, making it possible, through these parameters, to view the profile and care demands of this population.

Descriptors: Aged; Caregiver; Anxiety; Depression; Primary Health Care.
\end{abstract}

\section{RESUMO}

Objetivo: Analisar os sintomas de ansiedade e depressão em cuidadores informais de idosos dependentes em domicílio. Métodos: Estudo analítico, transversal, realizado no município de Teresina (PI), com cuidadores informais de idosos dependentes. A coleta de dados ocorreu no período de novembro de 2017 a fevereiro de 2018, por meio de um formulário de caracterização do idoso dependente e seu cuidador, Inventário de Ansiedade de Beck (BAl) e Inventário de Depressão de Beck (BDI). Utilizou-se o modelo de regressão linear forward para identificação das variáveis preditoras de ansiedade e depressão. Resultados: Constatou-se que $18,4 \%$ dos cuidadores apresentaram sintomas de depressão; e $14 \%$, ansiedade moderada a severa. Houve correlação entre ansiedade e depressão $(p=0,000)$. Conclusão: Os achados deste estudo possibilitam a avaliação da ansiedade e depressão nos cuidadores de idosos dependentes, sendo possível, mediante tais parâmetros, visualizar o perfil e as demandas de cuidado dessa população.

Descritores: Idoso; Cuidadores; Ansiedade; Depressão; Atenção Primária à Saúde.

\section{RESUMEN}

Objetivo: Analizar los síntomas de ansiedad y depresión en cuidadores informales de ancianos dependientes en domicilio. Métodos: Estudio analítico, transversal, realizado en el municipio de Teresina (PI), con cuidadores informales de ancianos dependientes. La recogida de datos ocurrió en el período de noviembre de 2017 a febrero de 2018, por medio de un formulario de caracterización del anciano dependiente y su cuidador, Inventario de Ansiedad de Beck (BAI) e Inventario de Depresión de Beck (BDI). Se utilizó el modelo de regresión lineal forward para identificación de las variables predictoras de ansiedad y depresión. Resultados: Se constató que $18,4 \%$ de los cuidadores presentaron síntomas de depresión; y $14 \%$, ansiedad moderada a severa. Hubo correlación entre ansiedad y depresión $(p=0,000)$. Conclusión: Los hallados de esto estudio posibilitan la evaluación de la ansiedad y depresión en los cuidadores de ancianos dependientes, siendo posible, mediante tales parámetros, visualizar el perfil y las demandas de cuidado de esa población.

Descriptores: Anciano; Cuidadores; Ansiedad; Depresión; Atención Primaria de Salud.

Submission: 12-03-2019 Approval: 06-12-2020 


\section{INTRODUCTION}

Population aging is a phenomenon of global magnitude and drives important social, economic and health changes ${ }^{(1-2)}$. Changes related to aging associated with exteroceptive and interoceptive factors tend to increase the risk for diseases and disabilities and reduce the functional capacity of the elderly ${ }^{(3)}$.

In view of the increase in the proportion of elderly people with limitations to perform basic and instrumental activities of daily living, the index of people in situations of vulnerability, with a high degree of dependency, who need long-term care is enhanced ${ }^{(4-5)}$. In this context, the figure of the caregiver emerges, who can exercise the function in a formal or informal character and is responsible for providing care focused on basic, social and rehabilitation needs at home ${ }^{(6)}$.

In Brazil, care for the elderly is culturally attributed to an informal support network, without remuneration and training, whose members, due to their direct contact and the high demand for care offered, undergo a long and stressful workday in exclusive and full-time dedication ${ }^{(7-9)}$. This context of continuous care increases the risk of functional disability, exposes the caregiver to a process of overload in care and, thus, generates repercussions at work, leisure and self-care, which negatively impacts their physical and mental well-being. From this perspective, the indispensability of the quality care process stands out and the expansion of strategies that have the caregiver as the main subject ${ }^{(10-11)}$.

A survey of 36 caregivers of dependent elderly people attended at a Family Health Unit in Jequié (BA) revealed that $50 \%$ of the investigated caregivers had indications of depression and that this disorder is inversely proportional to the quality of life (QOL) (12). In addition, other studies have shown that caregivers reporting worse QOL were those who cared more for the elderly daily hours and who performed this task for more years, with interference in the psychological and social relations domain, and this highlights depression and anxiety as being effects adverse effects caused by the burden of care $\mathrm{e}^{(13-15)}$.

Thus, in view of the monetary and social damages and the impacts on the health of the caregiver and the elderly to whom care is provided, it is necessary to produce data that provide support for meeting these demands in a priority and resolutive manner by the health teams. That said, this study is justified by the possibility of assisting continuous and systematic processes with practical actions aimed at increasing emotional protection and social support, which can be useful in the prevention and reduction of anxiety and depression symptoms of elderly caregivers.

\section{OBJECTIVE}

To analyze the presence of symptoms of anxiety and depression in informal caregivers of dependent elderly people.

\section{METHOD}

\section{Ethical aspects}

This study was approved by the Research Ethics Committee of the Federal University of Piauí - UFPI and complied with national and international standards of ethics in research involving human beings, following the provisions of resolution $n$ 466/2012 and with the signature, by the participants, of the Free and Informed Consent Form (ICF).

\section{Design, location and period}

Analytical, cross-sectional study conducted with informal caregivers of elderly dependents in the municipality of Teresina (PI), from June 2017 to July 2018, in the context of the home. To guide the methodology, the Equator's STROBE instrument was used.

\section{Population and sample; inclusion and exclusion criteria}

The study population consisted of caregivers of dependent elderly assisted by Basic Health Units (UBS) included in the Program for Improving Access and Quality in Primary Care (PMAQ) in the northern region of the city of Teresina (PI). The northern region was chosen because it is the one with the largest number of PMAQ teams. The sample was calculated using proportional stratified sampling and defined based on the total number of dependent elderly people and their respective caregivers, who were recruited from November 2017 to February $2018^{(16)}$. It is important to highlight that the collection was census and all caregivers in the study area were visited.

At the end, 114 participants met the inclusion criteria, which were: age equal to or over 18 years old, being a lay caregiver, of a family character, of both sexes, who performed the function for at least three months and who were directly responsible for the care given to the elderly with complete dependence (impairment of all functions influenced by culture and learning and, also, simple vegetative functions, including the ability to eat alone) or incomplete (impairment of one of the simple vegetative functions [transfer and/or continence], in addition to, due to logical reasons, being dependent on bathing, dressing and using the bathroom $)^{(17)}$.

Caregivers with cognitive impairment according to the Mini Mental State Examination (MMSE) were excluded, as they were not able to answer the research instruments and because the test is indicated for study with the elderly, as was the case with most caregivers, in reason to be a tool that increases the accuracy of the data collected. This test assesses temporal and spatial orientation, immediate memory and word recall, calculation, naming, repetition, executing a command, writing, reading and visual motor skills, with scores ranging from 0 to 30 points ${ }^{(18)}$. The present study used the educational level as a score point as follows: for illiterate - 13 points; incomplete schooling from 1 to 4 years - 18 points; incomplete schooling for 4 to 8 years 18 points; schooling over 8 years - 26 points $^{(19)}$. The total of five caregivers did not reach the minimum score required according to years of schooling.

\section{Study Protocol}

The instruments used for data collection were: characterization form for dependent elderly and their caregiver, Beck Anxiety Inventory (BAI) ${ }^{(20)}$ and Beck Depression Inventory (IDB) 
(21). The form used for sociodemographic, clinical and care characterization was adapted from an instrument validated in 2014 for assessing the burden of the informal caregiver, covering the following variables related to the caregiver: age, sex, education, marital status, income, degree of kinship with the elderly, main occupation, care time, time dedicated to the elderly for days and hours of the week and at the weekend, help with care, presence of comorbidities, use of medications, body pain, changes in the body and self-perceived health ${ }^{(22)}$.

The Beck Anxiety Inventory (BAI) consists of a Likert-type scale composed of 21 questions to measure the intensity of anxiety symptoms. Indicates four levels of anxiety (normal, mild, moderate and severe) through a score ranging from 0 to 3 for each question, with a maximum total score of $63^{(20)}$. The Beck Depression Inventory (BDI) aims to measure behavioral manifestations and evaluate the intensity of depression through 21 items, each containing four alternatives that express the severity levels of depressive symptoms in relation to the last week, which can vary from 0 to 63 . The individual indicates only one of the alternatives, and the score for each category ranges from 0 to 3 , where 0 represents the absence of depressive symptoms; and 3, the presence of intense symptoms. The following categorization was used, previously used in other Brazilian studies ${ }^{(21)}$, to assess symptoms of depression: scores from 0 to 14 - no symptoms of depression; scores from 15 to 19 - symptoms of dysphoria; scores 20 or more - symptoms of depression.

From November 2017 to February 2018, data collection was performed by five previously trained nursing students on the use of the instruments. There were three home visits per shift, which lasted an average of 60 minutes; all, accompanied by the Community Health Agent (CHA). Subsequently, the MMSE was applied together with the other instruments of the study; all on the same day, including anxiety and depression scales.

\section{Analysis of results and statistics}

For statistical analysis, the variables were coded with subsequent double data entry in Microsoft Excel, and the analysis occurred using the IBM SPSS software, version 21.0 (SPSS Inc. Chicago, IL, USA). For sociodemographic and clinical characterization, descriptive analyzes were performed using measures of central tendency and dispersion. The normality of the variables was verified by the Kolmogorov-Smirnov test. For association between the sociodemographic and clinical variables of caregivers with anxiety and depression scores, Pearson's chi-square test and Fisher's exact test were used. For correlation between anxiety and depression scores, Spearman's Rho correlation test was used. The level of significance adopted was $5 \%$ for two-tailed hypothesis testing.

\section{RESULTS}

Among the informal caregivers of dependent elderly people investigated in this study, there was a greater distribution of females, $92.1 \%(n=105)$, and the average age was $48.80 \pm 12.59$ years, in which $19.29 \%$ ( $n=22$ ) were also elderly. It was found that $93 \%(n=106)$ of the caregivers were educated, $62.3 \%$ ( $n$ = 71) were married or in a domestic partnership, the monthly income was $\mathrm{R} \$ 973.18 \pm 1072.01$, and $91,2 \%(\mathrm{n}=104)$ were not professionally active. As for kinship, $93.9 \%(n=107)$ of caregivers were family members. Living with the elderly, $78.9 \%(n=90)$ of the participants.

With regards to the clinical characteristics of caregivers, it was observed that $48.2 \%(n=55)$ had comorbidities, and $44.7 \%(n=$ 51) used medication continuously. They claimed to have body pain, $76.3 \%(n=87)$, with $34.2 \%(n=39)$ reporting the onset of these pains after the elderly need care; and $49.1 \%(n=56)$, the permanence of pain after providing care to the elderly. In addition, $43 \%$ ( $n=$ 49) confirmed the presence of changes in body and health after providing care to the elderly, and $54.4 \%(n=62)$ rated their health as good. The descriptive analysis of the sample is shown in Table 1.

Regarding the care provided by the caregiver to the bedridden elderly, it was found that the average care time in months is 83.82 \pm 74.18 , with a minimum of 3 and a maximum of 360 months. Dependent on the hours of the day dedicated to caring for the elderly from Monday to Friday, it was noted that on average it is $93.35 \pm 35.22$ hours, with a minimum of 15 and a maximum of 120 hours. Regarding the weekend hours dedicated to caring for the elderly, it was shown that there are $37.33 \pm 14.81$ hours, with a minimum of 5 and a maximum of 48 hours. Subsequently, with regards assistance in caring for the elderly, 71.9\% $(n=82)$ reported that they received help.

The average depression score was $9.0 \pm 8.8$ with a minimum of 0 and a maximum of 38 points. It was observed, among the total of caregivers, that $72.8 \%(n=83)$ did not present depressive symptoms, $8.8 \%(n=10)$ showed symptoms of dysphoria, and $18.4 \%(n=21)$ showed depression symptoms. The anxiety score, on the other hand, showed an average of $8.5 \pm 11.5$, with a minimum of 0 and a maximum of 50 points. And $53.5 \%$ ( $n=$ $61)$ had a normal anxiety level; $21.9 \%(n=25)$, mild to moderate anxiety; $14 \%(n=16)$, moderate to severe anxiety; and 10.5\% (n $=12$ ), severe anxiety.

The frequencies of anxiety symptoms presented from moderate to severe in the last week by informal caregivers of dependent elderly people are shown in Figure 1; and in Figure 2, depressive symptoms.

It is added that there was a significant association between anxiety and depression scores with the variables: help for instrumental activities of daily living (IADLs), comorbidities, medication for continuous use, pain in the body, pain after care, changes in the body and health and self-perceived health (Tables 1 and 2). There was also a positive correlation between anxiety and depression ( $p<0.001 ; \mathrm{Cl}$ : 99\%, $a=0.001$ ).

When analyzing the association between anxiety and sociodemographic and clinical characteristics of the caregiver, a significant association was observed with IADLs $(p<0.001)$, comorbidities ( $p$ $=0.008)$, medication for continuous use $(p=0.000)$, body pain $(p$ $=0.003)$, , pain after care $(p=0.004)$, changes in body and health $(p=0.007)$ and self-perceived health $(p=0.000)$.

When analyzing the association between depression and sociodemographic and clinical characteristics of the caregiver, a significant association was observed with IADLs $(p=0.004)$, comorbidities $(p=0.002)$, medication for continuous use $(p=$ $0.001)$, body pain $(p=0.002))$, pain after care $(p=0.025)$, changes in health and body $(p=0.001)$ and self-perceived health $(p=0.000)$. 


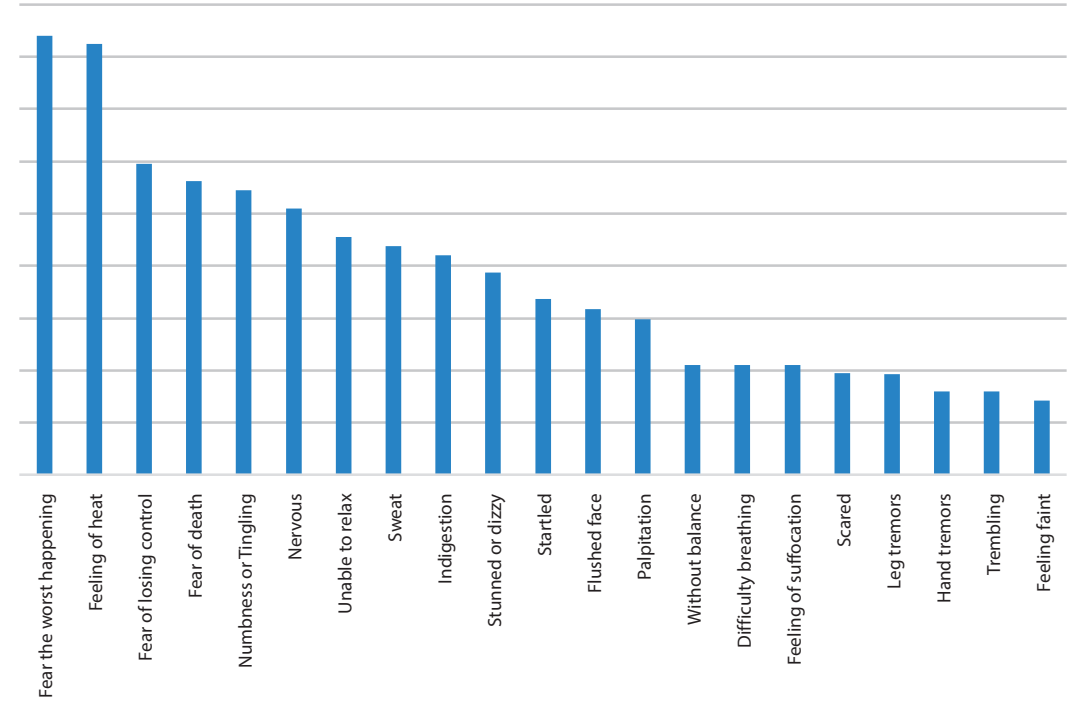

Figure 1 - Anxiety symptoms presented with moderate to severe intensity in the last week

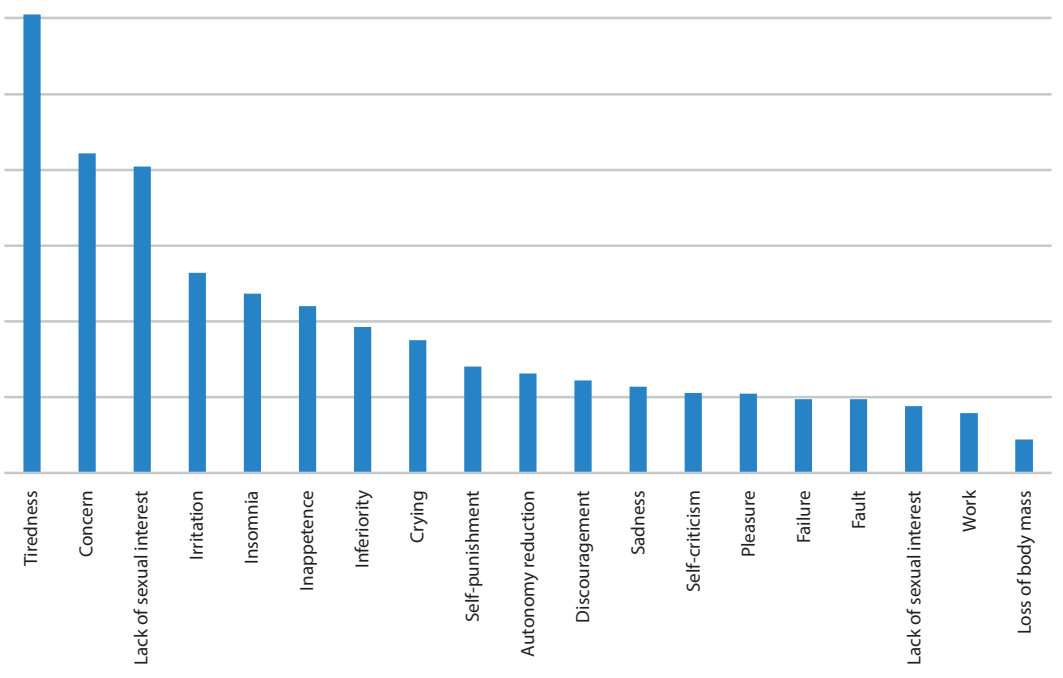

Figure 2 - Symptoms of depression presented in a moderate to severe form in the last week

Table 1 - Cross-analysis of anxiety with the caregiver's sociodemographic and clinical characteristics, Teresina, Piauí, Brazil, 2019

\begin{tabular}{|c|c|c|c|}
\hline \multirow[b]{2}{*}{ Variables } & \multicolumn{2}{|c|}{ Anxiety } & \multirow[b]{2}{*}{$\begin{array}{c}p \\
\text { value }\end{array}$} \\
\hline & $\begin{array}{c}\text { Normal to } \\
\text { Moderate } \\
\mathbf{n}(\%)\end{array}$ & $\begin{array}{c}\text { Moderate } \\
\text { to severe } \\
\mathbf{n}(\%)\end{array}$ & \\
\hline Does the caregiver live with the elderly person? & & & $0.494^{1}$ \\
\hline Yes & 57 & 33 & \\
\hline No & 17 & 7 & \\
\hline Is your main activity to be a caregiver for the elderly person? & & & $0.162^{2}$ \\
\hline Yes & 65 & 39 & \\
\hline No & 9 & 1 & \\
\hline $\begin{array}{l}\text { Does the caregiver count on help to care for the elderly } \\
\text { person? }\end{array}$ & & & $0.159^{\prime}$ \\
\hline Yes & 50 & 32 & \\
\hline No & 24 & 8 & \\
\hline Does the caregiver have help for BADLs? & & & $0.670^{1}$ \\
\hline Yes & 47 & 27 & \\
\hline No & 27 & 13 & \\
\hline
\end{tabular}

\section{DISCUSSION}

The characterization of study participants revealed the largest number of female caregivers, similar to that identified in national surveys ${ }^{(23-24)}$. In Brazil, women are culturally responsible for the care of elderly and sick members of their family. Despite historically acquired rights, social changes and family composition, women are still expected to assume the role of caregiver ${ }^{(25)}$.

Most of these caregivers were literate. It is known that education is a relevant factor, since this element facilitates the understanding of the care that should be offered to the elderly, such as assistance with medications, follow-up consultations, diet administration and also in the guidelines provided by the health team ${ }^{(26)}$.

Regarding marital status, there was a predominance of caregivers who had a partner, which corroborates the findings of national studies ${ }^{(25,27)}$. The presence of a spouse assists the caregiver in the care provided to the elderly and constitutes a protective factor that reduces the personal exhaustion of the caregiver. The support network of most informal caregivers is mainly made up of family members, so those who are single, widowed and divorced and, therefore, do not maintain a stable union, would have a deficiency in this support ${ }^{(28)}$.

In addition, the majority of caregivers were family members and lived with the elderly, which corroborates a national study with informal caregivers of dependent elderly people, in which $42.86 \%$ were children, and $21.43 \%$, spouses ${ }^{(29)}$. The literature points out that there is a moral obligation imposed by the family culture that children should take care of their parents as dependents, for a return of care when they were children and also for the feeling of affection that exists and that endures in other generations ${ }^{(30)}$.

The average income of the participants in this investigation can be considered low and deserves to be highlighted, given that most elderly caregivers abdicate their jobs to dedicate themselves to the care provided to the elderly person. Internationally, a study conducted in Iran found that marital status, sex and low income are variables that have a significant association with levels of anxiety and depression. This relationship can be explained by the stress and physical wear caused by financial and care aspects, which contribute to the emergence of mood disorders ${ }^{(31)}$.

Considering professional occupation, there was a predominance of caregivers who were not active in the labor market, having time to care for the home and the elderly. The situation 


\begin{tabular}{|c|c|c|c|}
\hline \multirow[b]{2}{*}{ Variables } & \multicolumn{2}{|c|}{ Anxiety } & \multirow[b]{2}{*}{$\begin{array}{c}p \\
\text { value }\end{array}$} \\
\hline & $\begin{array}{c}\text { Normal to } \\
\text { Moderate } \\
\text { n(\%) }\end{array}$ & $\begin{array}{c}\text { Moderate } \\
\text { to severe } \\
n(\%)\end{array}$ & \\
\hline Does the caregiver count on help for IADLs? & & & $0.000^{2}$ \\
\hline Yes & 7 & 13 & \\
\hline No & 70 & 27 & \\
\hline $\begin{array}{l}\text { Does the caregiver have help with the therapeutic needs of } \\
\text { the elderly person? }\end{array}$ & & & $0.099^{1}$ \\
\hline Yes & 17 & 15 & \\
\hline No & 57 & 25 & \\
\hline Does the caregiver have a disease/health problem? & & & $0.008^{1}$ \\
\hline Yes & 29 & 26 & \\
\hline No & 45 & 14 & \\
\hline Does the caregiver use any medication for continuous use? & & & $0.000^{1}$ \\
\hline Yes & 24 & 27 & \\
\hline No & 50 & 13 & \\
\hline Does the caregiver feel pain in the body? & & & $0.003^{2}$ \\
\hline Yes & 50 & 37 & \\
\hline No & 24 & 3 & \\
\hline Did these pains arise after the elderly person needed care? & & & $0.074^{1}$ \\
\hline Yes & 21 & 18 & \\
\hline No & 53 & 22 & \\
\hline Does the pain remain after the elderly person is cared for? & & & $0.004^{1}$ \\
\hline Yes & 29 & 27 & \\
\hline No & 45 & 13 & \\
\hline $\begin{array}{l}\text { Do you have health and body changes after becoming a } \\
\text { caregiver? }\end{array}$ & & & $0.007^{1}$ \\
\hline Yes & 25 & 24 & \\
\hline No & 49 & 16 & \\
\hline Caregiver's self-perceived health & & & $0.000^{1}$ \\
\hline Good & 45 & 7 & \\
\hline Regular/bad & 29 & 33 & \\
\hline Total & 74 & 40 & \\
\hline
\end{tabular}

Note: $1=$ Pearson's chi-square. 2 = Fisher's exact test. ${ }^{*} \mathrm{Cl}: 95 \%, a=0.005$.

Table 2 - Cross-analysis of depression with the caregiver's sociodemographic and clinical characteristics, Teresina, Piauí, Brazil, 2019

\begin{tabular}{|c|c|c|c|}
\hline \multirow[b]{2}{*}{ Variables } & \multicolumn{2}{|c|}{ Depression } & \multirow[b]{2}{*}{$\begin{array}{c}p \\
\text { value }\end{array}$} \\
\hline & $\begin{array}{l}\text { Without } \\
\text { depression } \\
\text { (n) }\end{array}$ & $\begin{array}{c}\text { Symptoms } \\
\text { of dysphoria } \\
\text { and depression }\end{array}$ & \\
\hline Does the caregiver live with the elderly person? & & & $0.903^{1}$ \\
\hline Yes & 50 & 40 & \\
\hline No & 13 & 11 & \\
\hline Is your main activity to be a caregiver for the elderly? & & & $0.751^{2}$ \\
\hline Yes & 58 & 46 & \\
\hline No & 5 & 5 & \\
\hline Does the caregiver count on help to care for the elderly? & & & $0.895^{1}$ \\
\hline Yes & 45 & 37 & \\
\hline No & 18 & 14 & \\
\hline Does the caregiver have help for BADLs? & & & $0.663^{1}$ \\
\hline Yes & 42 & 32 & \\
\hline No & 21 & 19 & \\
\hline Does the caregiver count on help for IADLs? & & & $0.004^{2}$ \\
\hline Yes & 4 & 13 & \\
\hline No & 59 & 38 & \\
\hline $\begin{array}{l}\text { The caregiver has help with the therapeutic needs of the } \\
\text { elderly (leisure, consultations, physiotherapy services) }\end{array}$ & & & $0.260^{1}$ \\
\hline Yes & 15 & 17 & \\
\hline No & 48 & 34 & \\
\hline Does the caregiver have a disease/health problem? & & & $0.002^{1}$ \\
\hline Yes & 22 & 33 & \\
\hline No & 41 & 18 & \\
\hline Does the caregiver use any medication for continuous use? & & & $0.001^{1}$ \\
\hline Yes & 19 & 32 & \\
\hline No & 44 & 19 & \\
\hline
\end{tabular}

found contributes to the care for the elderly being constant and, therefore, more tiring. This reality still favors the existence of a financial burden that, when added to the demand for resources for the health of the elderly, can result in a feeling of anguish on the part of the caregiver who wishes to offer the best to his relative ${ }^{(32)}$.

It is added that the caregivers stated that they have a support network to help care for the elderly. This data is a positive aspect, since the division of care with a secondary caregiver contributes to a lesser burden. However, even if there is assistance in carrying out the tasks, there is still the role of the main caregiver, who in most cases assumes the actions of care almost entirely. This reality can lead to compromise in the routine of the person responsible for caring for the elderly and an increase in burden, which reveals the need for strategies for a more equal division of care, when this is possible ${ }^{(27)}$.

Regarding the health profile, the majority of participants reported living with one or more diseases and stated that they use drugs continuously. The presence of comorbidities is a factor that deserves to be highlighted, as the presence of diseases can be a direct or indirect result of the role performed by the caregiver and has a significant association with mental strain, which can be represented by anxiety and depression. Nevertheless, polypharmacy is a common practice, mainly in an attempt to relieve pain and solve problems related to indisposition and sleep. In addition, studies indicate that caregivers who take a greater number of medications have a greater physical and mental burden and, therefore, need continuous health care ${ }^{(27,33)}$.

In this study, there was a significant association between the variable "presence of pain" and symptoms of anxiety and depression. Most caregivers reported the constant presence of such symptom, which may be a consequence of the intense use of physical strength and technical unpreparedness to provide care, which predisposes to overload of muscles and joints. This reality directly affects the quality of life of caregivers and, when associated with other changes resulting from care, such as less leisure time and social life, it can cause symptoms of mood disorders ${ }^{(8,28)}$.

With regard to the subjective perception of their health condition, the majority felt changes in their body and health after assuming the role of caregiver; and considered their health good. Similar results were obtained by another national study, in which $56.6 \%$ of caregivers considered their health to be good or very good ${ }^{(11)}$. 


\begin{tabular}{|c|c|c|c|}
\hline \multirow[b]{2}{*}{ Variables } & \multicolumn{2}{|c|}{ Depression } & \multirow[b]{2}{*}{$\begin{array}{c}p \\
\text { value }\end{array}$} \\
\hline & $\begin{array}{l}\text { Without } \\
\text { depression } \\
\text { (n) }\end{array}$ & $\begin{array}{c}\text { Symptoms } \\
\text { of dysphoria } \\
\text { and depression }\end{array}$ & \\
\hline Does the caregiver feel pain in the body? & & & $0.002^{1}$ \\
\hline Yes & 41 & 46 & \\
\hline No & 22 & 5 & \\
\hline Did these pains arise after the elderly person needed care? & & & $0.071^{1}$ \\
\hline Yes & 17 & 22 & \\
\hline No & 46 & 29 & \\
\hline Does the pain remain after the elderly person is cared for? & & & $0.025^{1}$ \\
\hline Yes & 25 & 31 & \\
\hline No & 38 & 20 & \\
\hline $\begin{array}{l}\text { Do you have changes in health after becoming a } \\
\text { caregiver? }\end{array}$ & & & $0.001^{1}$ \\
\hline Yes & 18 & 31 & \\
\hline No & 45 & 20 & \\
\hline Caregiver's self-perceived health & & & 0.000 \\
\hline Good & 38 & 14 & \\
\hline Regular/bad & 25 & 37 & \\
\hline Total & 63 & 51 & \\
\hline
\end{tabular}

Note: 1 = Pearson's chi-square. 2 = Fisher's exact test ${ }^{*} \mathrm{Cl}: 95 \% ; \alpha=0.005$.

Regarding the characteristics of care, most caregivers perform their function for a prolonged time, on average 83.82 months, and receive assistance in this task. This finding is ratified by other Brazilian studies and reinforces the idea that, over time, the activity of caring becomes extremely tiring and stressful, negatively affecting self-care and triggering various health problems, such as: depression, anxiety, muscle pain, recurring headache and insomnia. Furthermore, the importance of support in care is highlighted, both for maintaining the physical and psychological well-being of the elderly as well as the caregiver. Thus, there is a strengthening of social interactions and reduction of physical and mental overloads ${ }^{(34)}$.

In the analysis of the Beck Depression Inventory (BDI), the prevalence of caregivers of elderly people who did not show symptoms of depression was found. In contrast, a study carried out in Turkey to determine the state of depression of home caregivers showed that $61.1 \%$ of respondents had depression. Although divergences are found in the studies, the importance of identifying high-risk groups for the disorder is highlighted, in view of the demand for stressful work and the lack of time to practice protective behaviors for depression, such as social interaction, leisure activities and physical exercise. In addition, the presence of a secondary caregiver helps to reduce the burden of care, which can directly impact the minimization of depressive symptoms ${ }^{(35)}$.

Regarding the symptoms of anxiety, the present study demonstrated that the majority of caregivers of elderly people surveyed had a minimum degree of anxiety. Such information can be explained by the fact that the majority of the elderly have incomplete dependence, being independent for most basic activities of daily living, which thus reduces, the demand for care and consequently influences the reduction of anxiety symptoms. Confirming this, international studies show that dependent elderly people generate greater burden of care and higher levels of anxiety ${ }^{(36)}$.

When comparing which sociodemographic and clinical characteristics were related to the caregivers' symptoms of anxiety and depression, the following factors were identified as significant: physical burden of caregivers, represented by the presence of body pain; changes in health; self-perceived health; and dependence of the elderly in basic activities of daily living. In this sense, the need for support to the caregiver by both the family and the health systems is highlighted, in order to provide a reduction in physical wear and prevent the appearance of mental disorders ${ }^{(37)}$.

\section{Study limitations}

As a limitation of the study, the cross-sectional design stands out, which did not allow establishing causality between the variables and the outcome. In addition, the sample size may limit the generalization of the data, since the study was conducted in only one region of the municipality.

\section{Contributions to the field of Nursing}

The present study demonstrates the need, within the scope of the health and nursing system, for interventions aimed at improving the health and functional conditions of the elderly, as well as formal and constant assistance to informal caregivers who are engaged in the care and assistance of the basic needs of those who are dependent. In addition, the study emphasizes the importance of assessing not only the physical weariness of the caregiver, such as the presence of pain and illness, but also mental wear, with emphasis on the presence of symptoms of depression and anxiety, considering that this negative picture influences not only the QOL of the caregiver, but also the assistance provided to the elderly.

\section{CONCLUSION}

Of the informal caregivers participating in this study, $18.4 \%$ had symptoms of depression, and $8.8 \%$ had symptoms of dysphoria, as well as $10.5 \%$ had severe levels of anxiety, $14.0 \%$ moderate to severe levels, and 21, 9\% mild and moderate levels. It was also verified the existence of a significant relationship between anxiety and depression perceived in the informal caregiver.

This result implies the need for a reorganization of the care plans that are elaborated within the Primary Care, which should also be aimed at the caregiver, using mainly instruments that provide early screening for these symptoms. Still, knowledge in the provision of care is needed to relieve these anxiety symptoms and prevent the onset of depression.

In addition, it is necessary for the health team to know the profile of elderly caregivers and their difficulties, which allows professionals to plan care more satisfactorily, integrating this caregiver in the implementation of actions aimed at reducing risks and increasing quality of life of the elderly person, caregiver and family. For this, the guidelines given by health professionals to informal caregivers must be continuous and easy to understand and must provide correct and quality care, since technical training in informal care is absent. 
The results found in the present study are of great relevance in the assessment of anxiety and depression, as well as in the characterization of elderly people bedridden at home and their caregivers, making it possible, through these parameters, to view the profile and the care demands of this population. In this way, health professionals, especially nurses, can be assisted in planning quality and humanized care through health promotion, prevention and recovery actions seeking to satisfy the needs of this population group. In addition to these assistance contributions, it is believed that the findings of this study may serve as a basis for future similar research with different methodological approaches, to highlight other associated factors and provide elements to alleviate the symptoms of anxiety and depression.

\section{REFERENCES}

1. United Nations. Department of Economic and Social Affairs, Population Division. World Population Ageing[Internet] 2017 [cited 2020 Feb 19]. Available from: https://www.un.org/en/development/desa/population/publications/pdf/ageing/WorldPopulationAgeing2019Highlights.pdf

2. Instituto Brasileiro de Geografia e Estatística - IBGE, Diretoria de Pesquisas, Coordenação de População e Indicadores Sociais. Estimativa da população residente [Internet]. 2018 [cited 2020 Feb 19]. Available from:www.ibge.gov.br

3. Harridge SR, Lazarus NR. Physical activity, aging, and physiological function. Physiol [ Internet]. 2017 [cited 2020 Feb 19];32(2):152-61. Available from:https://journals.physiology.org/doi/full/10.1152/physiol.00029.2016

4. Barbosa KTF, Costa KNDFM, Pontes MDLDF, Batista PSDS, Oliveira FMRLD, Fernandes MDGM. Envelhecimento e vulnerabilidade individual: um panorama dos idosos vinculados à Estratégia de Saúde da Família. Texto Contexto Enferm [Internet]. 2017 [cited 2020 Feb 19];26(2). Available from: https://www.scielo.br/pdf/tce/v26n2/0104-0707-tce-26-02-e2700015.pdf

5. Minayo MCS. The imperative of caring for the dependent elderly person. Cien Saude Coletiva [Internet]. 2019 [cited 2020 Feb 19];24(1):24752. Available from: https://www.scielosp.org/article/csc/2019.v24n1/247-252/en/

6. Kobayasi DY, Rodrigues RAP, Fhon JRS, Silva LM, Souza AC, Chayamiti EMPC. Sobrecarga, rede de apoio social e estresse emocional do cuidador do idoso. Av Enferm [Internet]. 2019 [cited 2020 Feb 19]; 37 (2):140-148. Available from: http://www.scielo.org.co/pdf/aven/ v37n2/0121-4500-aven-37-02-140.pdf

7. Albuquerque FKO, Silva MC, Lima NKF, Gerbasi HCLM. Qualidade de vida em cuidadores de idosos: uma revisão integrativa. Rev Enferm Atual Derm [Internet]. 2019 [cited 2020 Feb 19];87(25). Available from: http://www.revistaenfermagematual.com.br/index.php/revista/ article/view/189/91

8. Mendes PN, Figueiredo MDLF, Santos AMR, Fernandes MA, Fonseca RSB. Sobrecargas física, emocional e social dos cuidadores informais de idosos. Acta Paul Enferm. 2019;32(1):87-94. doi: 10.1590/1982-0194201900012

9. Couto AM, Caldas CP, Castro EAB. Home care for dependent elderly patients by caregivers with overload and stress. Rev Pesqui: Cuid Fundam. 2019;11(4):944-50. Available from: 10.9789/2175-5361.2019.v11i4.944-950

10. Nunes DP, Brito TRPD, Duarte YADO, Lebrão ML. Caregivers of elderly and excessive tension associated to care: evidence of the Sabe Study. Rev Bras Epidemiol[Internet]. 2018[cited 2020 Feb 19];21. Available from: https://www.scielosp.org/article/rbepid/2018.v21suppl2/e180020/en/

11. Luchesi BM, Souza ÉN, Gratão ACM, GA, Inouye K, Silva AT, Pavarini SCl. The evaluation of perceived stress and associated factors in elderly caregivers. Arch Gerontol Geriatr [Internet]. 2016 [cited 2020 Feb 19];67:7-13. doi: 10.1016/j.archger.2016.06.017

12. Sampaio LS, Santos SP, Silva MV, Sampaio TSO, Reis LA. Qualidade de vida e depressão em cuidadores de idosos dependentes. Rev APS [Internet]. 2018 [cited 2020 Feb 19];21(1). Available from: https://periodicos.ufj..br/index.php/aps/article/view/16235.

13. Mello JDA, Macq J, Van Durme T, Cès S, Spruytte N, Van AC, Declercq A. The determinants of informal caregivers' burden in the care of frail older persons: a dynamic and role-related perspective. Aging Mental Health [Internet]. 2016 [cited 2020 Feb 19];1-6. Available from: https:// www.tandfonline.com/doi/full/10.1080/13607863.2016.1168360

14. Duarte A, Joaquim N, Lapa F, Nunes C. Qualidade de vida e sobrecarga dos cuidadores informais dos pacientes idosos das unidades de cuidados de assistência domiciliar do Algarve (PT). SaBios Rev Saúde Biol[Internet]. 2018 [cited 2020 Feb 19];12(1):12-26. Available from: http://revista2.grupointegrado.br/revista/index.php/sabios2/article/view/1661

15. Henriques RTM, Cabana MCFL, Montarroyos UR. Prevalência de Transtornos mentais comuns e sua associação com a sobrecarga em cuidadores familiares de idosos. Mental [Internet]. 2018 [cited 2020 Feb 19];12(22):35-52. Available from: http://pepsic.bvsalud.org/pdf/ mental/v12n22/v12n22a04.pdf

16. Barbetta PA. (org.) Estatística Aplicada às Ciências Sociais. Santa Catarina: Editora UFSC; 2002. 389p.

17. Moraes EN. Avaliação multidimensional do idoso. Secretaria de Estado da Saúde do Paraná. Curitiba, 2018. 250p.

18. Melo DM, Barbosa AJG, Neri AL. Miniexame do Estado Mental: evidências de validade baseadas na estrutura interna. Avaliação Psicológica [Internet]. 2017 [cited 2020 Feb 19]; 16(2):161-168. Available from: http://pepsic.bvsalud.org/pdf/avp/v16n2/v16n2a07.pdf

19. Pereira N, Kochhann R., Zimmermann N, Fonseca RP. Mini-Exame do Estado Mental na avaliação neuropsicológica pós-TCE: aplicabilidades. Diaphora [Internet]. 2014 [cited 2020 Feb 19];12(2):58-63. Available from: http://www.sprgs.org.br/diaphora/ojs/index.php/diaphora/article/ view/72 
20. Reppold CT, Hutz CS. Evidências de validade da escala de avaliação de ansiedade em adolescentes brasileiros. Aval Psicol [Internet]. 2013 [cited 2020 Feb 19];12(2):131-6. Available from: https://dialnet.unirioja.es/servlet/articulo?codigo=5116481

21. Gandini RDC, Martins MDCF, Ribeiro MDP, Santos DTG. Inventário de Depressão de Beck - BDI: validação fatorial para mulheres com câncer. Psicol USF. 2007;12(1):23-31. doi:10.1590/S1413-82712007000100004

22. Monteiro EA. Validação do questionário de avaliação da sobrecarga do cuidador informal em uma amostra de cuidadores brasileiros. [Tese][Internet]. Ribeirão Preto, USP, 2014[cited 2020 Feb 19]. Available from: https://www.teses.usp.br/teses/disponiveis/22/22132/tde21052014-154833/publico/EDILENEARAUJOMONTEIRO.pdf

23. Santana MS, Oliveira DL, Santos MM, Rangel RL, Chaves RN, Reis LA. Sobrecarga dos cuidadores familiares de idosos com dependência funcional. Rev Kairós: Gerontol [Internet]. 2018 [cited 2020 Feb 19];21(1):337-53. Available from: http://ken.pucsp.br/kairos/article/view/39799

24. Oliveira DL, Santos MM., Santana MS, Rangel RL, Alexandria PR., Chaves RN. Qualidade de vida do cuidador familiar de idosos com dependência funcional. Rev Uniabeu [Internet]. 2019 [cited 2020 Feb 19];12(30):446-60. Available from: https://revista.uniabeu.edu.br/ index.php/RU/article/view/3376

25. Queiroz RSD, Camacho ACLF, Gurgel JL, Assis CRDCD, Santos LMD, Santos MLSCD. Perfil sociodemográfico e qualidade de vida de cuidadores de idosos com demência. Rev Bras Geriatr Gerontol. 2018;21(2):205-14. doi: 10.1590/1981-22562018021.170170.

26. Santos-Orlandi AAD, Brito TRPD, Ottaviani AC, Rossetti ES, Zazzetta MS, Gratão ACM, Pavarini SCl. Perfil de idosos que cuidam de outros idosos em contexto de alta vulnerabilidade social. Esc Anna Nery. 2017;21(1). doi: 10.5935/1414-8145.20170013

27. Leite BS, Camacho ACLF, Joaquim FL, Gurgel JL, Lima TR, Queiroz RS. A vulnerabilidade dos cuidadores de idosos com demência: estudo descritivo transversal. Rev Bras Enferm. 2017;70(4):714-20. doi: 10.1590/0034-7167-2016-0579

28. Jesus ITM, Orlandi AAS, Zazzetta MS. Sobrecarga, perfil e cuidado: cuidadores de idosos em vulnerabilidade social. Rev Bras Geriatr Gerontol. 2018;21(2):199-209. doi: 10.1590/1981-22562018021.170155

29. Santos GS, Cunha ICKO. Visita domiciliar a idosos: características e fatores associados. Rev Enferm C Oeste Min[Internet]. 2017 [cited 2020 Feb 19];7. Available from: http://www.seer.ufsj.edu.br/index.php/recom/article/view/1271

30. Valle-Alonso D, Hernández-López IE, Zúñiga-Vargas ML, Martínez-Aguilera P. Sobrecarga y Burnout en cuidadores informales del adulto mayor. Enferm Univ. 2015;12(1):19-27. doi: 10.1016/j.reu.2015.05.004

31. Heravi-Karimooi M, Rejeh N, Montaigne A. Anxiety and depression in caregivers of elderly with Alzheimer. Payesh [Internet]. 2019 [cited 2020 Jun 03];18(6):579-87. Available from: http://payeshjournal.ir/article-1-1244-en.pdf

32. Garbaccio JL, Tonaco LABL. Characteristics and Difficulties of Informal Caregivers in Assisting Elderly People. Rev Pesqui: Cuid Fundam [Internet]. 2019 [cited 2020 Feb 19];11(3):680-6. Available from: http://www.seer.unirio.br/index.php/cuidadofundamental/article/view/6655/pdf

33. Santos BE, Koetz LCE. O perfil socioepidemiológico e a autopercepção dos cuidadores familiares sobre a relação interpessoal e o cuidado com idosos. Rev ACRED[Internet]. 2017[cited 2020 Feb 19];7(3):115-32. Available from: https://dialnet.unirioja.es/servlet/articulo?codigo=6130788

34. Brigola AG, Luchesi BM, Rossetti ES, Mioshi E, Inouye K, Pavarini SCI. Perfil de saúde de cuidadores familiares de idosos e sua relação com variáveis do cuidado: um estudo no contexto rural. Rev Bras Geriatr Gerontol. 2017;20(3):410-22. doi: 10.1590/1981-22562017020.160202

35. Arican B, Guney M, Akbal N, Demiral BH, Nadir A, Kokar IK, Sargin M. Determining depression level of caregivers providing home healthcare services.Northern clinics of Istanbul[Internet]. 2016 [cited 2020 Jun 03];3(2):1 18. Available from:https://www.ncbi.nlm.nih.gov/pmc/articles/ PMC5206461

36. Hu P, Yang Q, Kon L, Hu L, Zeng L. Relationship between the anxiety/depression and care burden of the major caregiver of stroke patients. Med [Internet]. 2018 [cited 2020 Jun 03];97(40). Available from: https://www.ncbi.nlm.nih.gov/pmc/articles/PMC6200450

37. Sarıtaş SÇ, Işık K. Determining the Care Burden and Anxiety Levels of Caregivers of Elderly Patients with Heart Failure. J Cardiovasc Nurs [Internet]. 2017 [cited 2020 Jun 03];8(16):55-62. Available from: https://pdfs.semanticscholar.org/e457/9b7dfe5a69506773183f167ff198a112b65c.pdf 